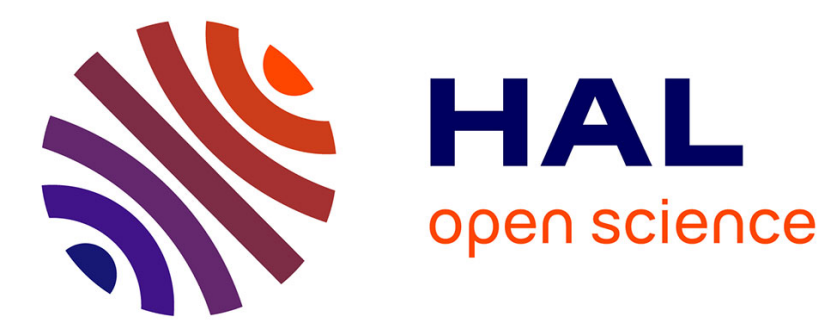

\title{
APPLICATION OF MEMS TECHNOLOGY TO MICRO DIRECT METHANOL FUEL CELL
}

Xiaowei Liu, Chunguang Suo, Yufeng Zhang, Haifeng Zhang, Ch. Dhum, Weiping Chen, Xuebin Lu

\section{- To cite this version:}

Xiaowei Liu, Chunguang Suo, Yufeng Zhang, Haifeng Zhang, Ch. Dhum, et al.. APPLICATION OF MEMS TECHNOLOGY TO MICRO DIRECT METHANOL FUEL CELL. DTIP 2006, Apr 2006, Stresa, Lago Maggiore, Italy. 6 p. hal-00189313

\section{HAL Id: hal-00189313 https://hal.science/hal-00189313}

Submitted on 20 Nov 2007

HAL is a multi-disciplinary open access archive for the deposit and dissemination of scientific research documents, whether they are published or not. The documents may come from teaching and research institutions in France or abroad, or from public or private research centers.
L'archive ouverte pluridisciplinaire HAL, est destinée au dépôt et à la diffusion de documents scientifiques de niveau recherche, publiés ou non, émanant des établissements d'enseignement et de recherche français ou étrangers, des laboratoires publics ou privés. 


\title{
DTIP
}

Stresa, Italy, 26-28 April 2006

\section{APPLICATION OF MEMS TECHNOLOGY TO MICRO DIRECT METHANOL FUEL CELL}

\author{
Xiaowei Liu*, Chunguang Suo, Yufeng Zhang, Haifeng Zhang, Weiping Chen, Xuebin Lu \\ (*Tel: +86 451 86413442, Fax: +86 451 86413441, email: 1xw@hit.edu.cn)
}

\begin{abstract}
In view of micro fuel cells, the silicon processes are employed for microfabrication of the micro direct methanol fuel cell ( $\mu$ DMFC). Using the MEMS technology we have successfully made single $\mu \mathrm{DMFC}$ as small as $10 \mathrm{~mm} \times 8 \mathrm{~mm} \times 3 \mathrm{~mm}$. The main reason for the use of MEMS processes is the prospective potential for miniaturization and economical mass production of small fuel cells. The double side deep wet etching for the gas channel and fuel chamber preparation and the formation of porous silicon (PS) layers for electrode supports by electrochemical process are the key technologies to improve the MEMS-based $\mu \mathrm{DMFC}$. Moreover, for the first time, the fabrication of electro-catalytic electrodes using electroless plating platinum and ruthenium (Pt-Ru) co-deposition method over PS substrates is introduced. Using the MEMS technology makes the batch fabrication of $\mu \mathrm{DMFCs}$ much easier and reduces the usage of rare metals.
\end{abstract}

\section{INTRODUCTION}

Recently, the demand for clean and renewable energy sources has significantly increased [1]. Due to the rapidly growing portable electronics market and the needs for leisure, military or telecommunication equipment, miniature fuel cells (FCs) have been attracting more and more attention by many research groups to generate power for MEMS and IC devices [2-7]. The micro direct methanol fuel cell ( $\mu$ DMFC) which uses liquid methanol without a reformer is considered as the most promising type of fuel cell for small power-supply units because of their advantage of ambient condition operation, which is most essential for portable application [8-10]. Liu et al. have reviewed the state-of-art on the silicon-based $\mu \mathrm{DMFC}[11]$.

However, much attention has been given to using the MEMS technology for fabrication of the current collector and flow channel of the micro fuel cells [12]. Our research work includes not only the fabrication of the structure of the $\mu \mathrm{DMFC}$, but also the preparation of the key components of the fuel cell, the electro-catalytic electrodes. Some papers $[13,14]$ reported that micro fuel cells containing porous silicon (PS) based membranes sandwiched between the electrodes as membrane electrolyte assemblies (MEA), which have inherent the conventional direct methanol fuel cells' disadvantages such as bulky in size, waste in rare metals, and difficulty in batch fabrications.

For the above-mentioned reasons, we provide a novel method of preparation electro-catalytic electrodes using electroless plating of rare metals on the porous silicon substrates as catalytic layers, which has many advantages may predigest the fabrication processes of the micro direct methanol fuel cells.

\section{PRINCIPLE}

A direct methanol fuel cell (DMFC) works through the principle of separating the oxidation of a fuel, such as the oxidation of methanol and the reduction of oxygen. Through electrochemical reactions, the oxidation and reduction processes take place at the anode and cathode, respectively. The methanol is oxidized and produces electrons, protons, and carbon dioxide. The electrons are released to an outer circuit at the anode and received through the same circuit at the cathode. Otherwise, the protons can transport through a proton exchange membrane (PEM) to the cathode, where to meet the electrons to form into water. Figure 1 illustrates the principle of a DMFC single cell.

Through the oxidation and reduction processes, the power of electricity is exported continually.

The following equations described the reactions of DMFCs.

Anode reaction:

$$
\mathrm{CH}_{3} \mathrm{OH}+\mathrm{H}_{2} \mathrm{O} \rightarrow \mathrm{CO}_{2}+6 \mathrm{H}^{+}+6 \mathrm{e}^{-}
$$

Cathode reaction:

$$
3 / 2 \mathrm{O}_{2}+6 \mathrm{H}^{+}+6 \mathrm{e}^{-} \rightarrow 3 \mathrm{H}_{2} \mathrm{O}
$$

Overall reaction

$$
3 / 2 \mathrm{O}_{2}+\mathrm{CH}_{3} \mathrm{OH} \rightarrow \mathrm{CO}_{2}+2 \mathrm{H}_{2} \mathrm{O}
$$




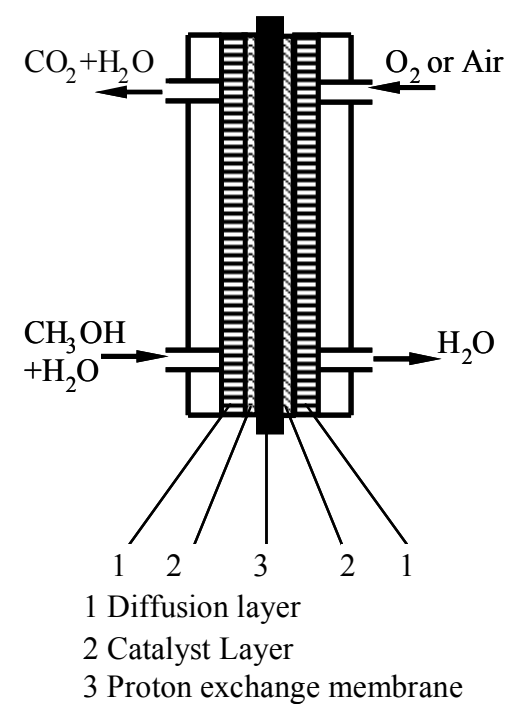

Fig. 1. Schematic principle of a DMFC single cell

\section{EXPERIMENTAL}

\subsection{Preparation of $\mu \mathrm{DMFC}$ using MEMS technology}

Figure 2 shows the process of a micro direct methanol fuel cell using the silicon process technology.

(1) $\mathrm{SiO}_{2}$ formation

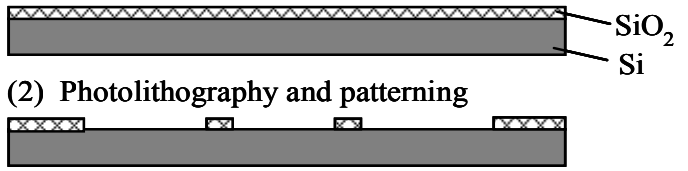

(3) Wet etching

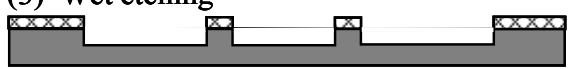

(4) $\mathrm{SiO}_{2}$ layer removal and anodization

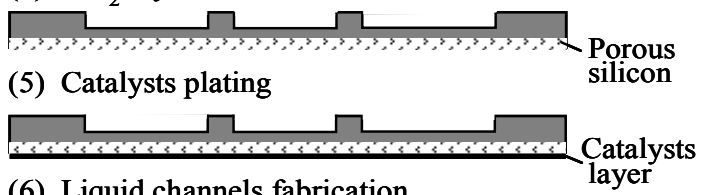

(6) Liquid channels fabrication

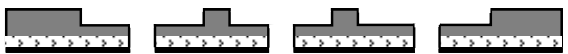

(7) Glass process and anodic bonding

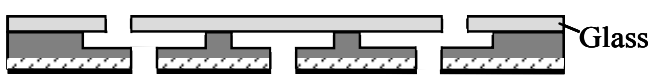

(8) PEM attachment

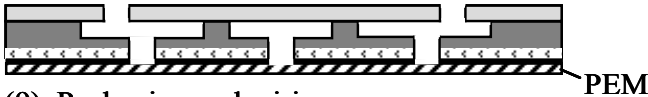

(9) Packaging and wiring

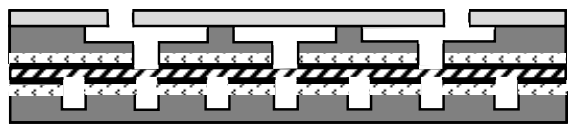

Fig. 2. Fabrication process of a $\mu \mathrm{DMFC}$
These processes employed silicon micromachining techniques including thermal oxidation, optical lithography, wet etching, silicon anodization, physical vapor deposition, electroless plating, laser beams cauterization, and anodic bonding. The starting material were two pieces of $3 \mathrm{in}$. diameter, $500 \mu \mathrm{m}$ thick double-side polished silicon waters, one used as the anodic electrodes material, the other as cathodal electrodes.

First $\mathrm{SiO}_{2}$ film is deposited on both the silicon substrates. To make fuel chambers and air flow channels, the $\mathrm{SiO}_{2}$ over one side the wafers is patterned by photolithography. Second wet etching method is employed to finish the structure both in anodic and cathodal electrodes. Third porous silicon (PS) layer is obtained on the substrates by silicon anodic etching method. As cathodal electrodes the PS layer is on the side of structure side, as anodic electrodes the PS layer is over against the structure side of the silicon wafer. Fourth the Pt or Pt-Ru alloy is deposited by electroless plating over the anodic silicon substrate and cathodal silicon substrate, respectively. Fifth the methanol fuel channels through the anodic substrates are produced by laser beam cauterization, as well as the fuel inlet and outlet in the glass cover. Then the proton exchange membrane (PEM) is sandwiched between the anodic and cathodal substrates, at last the fuel cell is packaged and finished.

During the fabrication processes, the method of design and achievement of wet etching deep fuel chamber in one side of the anode is possible to expand the fuel containing room without a corresponding increase in the fuel cell overall volume. The depth of the fuel chamber is about $230 \mu \mathrm{m}$. The advantages of using laser for fuel channels making are their precise location of the holes, their prompt service, and easy controlling of the size of the apertures. Geometric analysis reveals that the islands spreading across the chamber will help the fuel diffusion across the electrodes more symmetrical and the fuel can be used more effectively. The micro gas channels run through the cathodal substrate make the oxygen feed more sufficient than micro columns pattern. The PEM available is a kind of modified Nafion ${ }^{\circledR} 117$ membrane, we have other reports about the method of the membrane modification.

\subsection{Preparation of silicon-based electro-catalytic electrodes by electrochemical method}

The method of catalyst layer deposition reported here differs from previous work $[2,6]$, with the specific method of electroless plating Pt-deposition and Pt-Ru co-deposition on the PS substrates. Both anodic and cathodal substrates obtained the PS on the surface of the silicon wafer facing the PEM.

The PS layer is formed by anodic etching in a HF-ethanol solution (HF:ethanol:water $=1: 1: 1$ ) which is considered an effective and cheap fabrication method.

Catalyst being electroless deposited on PS brings 
three-dimensional features, which increase the specific surface area within a stated volume. Additionally, as high as $95 \%$ the utilization ratio of noble metal in electroless plating solution leads economizing platinum and ruthenium. Depending on the operation conditions, perfect thickness (about 150nm-200nm) of the Pt or Pt-Ru alloy deposition can be easily obtained. In order to improve the compactness between catalyst and PS substrate, a thin film of titanium was sputtered on the PS before catalyst deposition.

A SEM micrograph of Pt-Ru plating on PS is shown in Figure 3. Compare with vapor deposition and sputtering method, electroless plating will enhance the adherence of a catalyst layer to a substrate and improve the uniformity of the deposition surface.

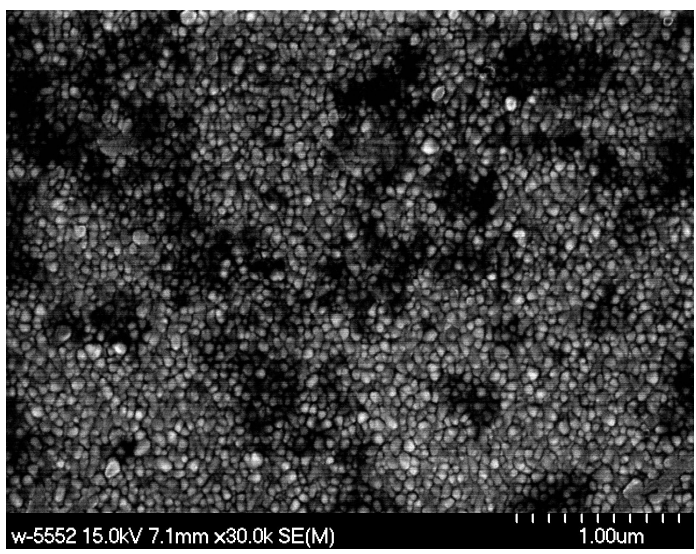

Fig. 3. SEM graph of Pt-Ru plating on PS

In order to tell components of the electroless plating film on the anodic substrate, EDX analysis was employed. The spectra results shows that the catalyst deposition is almost platinum and ruthenium without other impurity. By controlling the concentration of the $\mathrm{Pt}$ ion and $\mathrm{Ru}$ ion in the electroless plating solution, the different proportion of platinum and ruthenium in the catalyst layer can be easily gained. The EDX spectra of Pt-Ru catalyst deposition on the anodic PS substrate is shown figure 4.

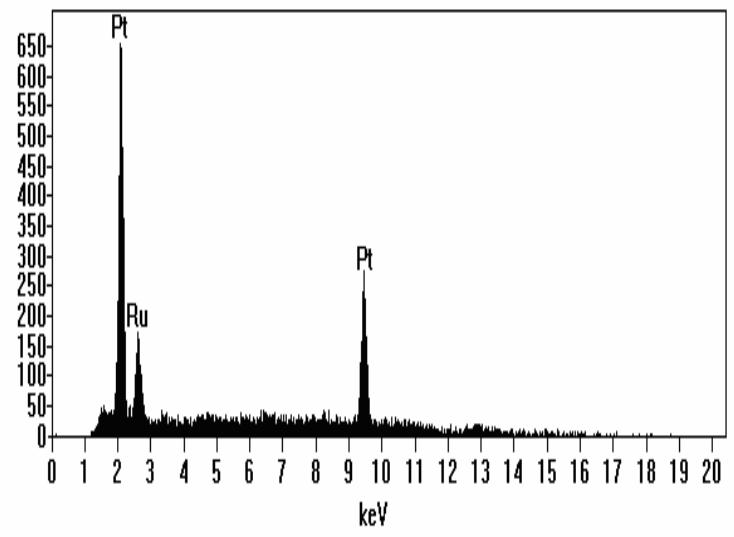

Fig. 4. EDX spectra of Pt-Ru deposition on PS

\subsection{Prototype of single micro direct methanol fuel cell}

The main four parts of the micro direct methanol fuel cell are the glass cover, silicon anode, PEM and silicon cathode. These parts are assembled to form the whole $\mu \mathrm{DMFC}$. The schematic view of the MEMS-based micro fuel cell components is shown in figure 5. The active area of the $\mu \mathrm{DMFC}$ is about $0.64 \mathrm{~cm}^{2}$.

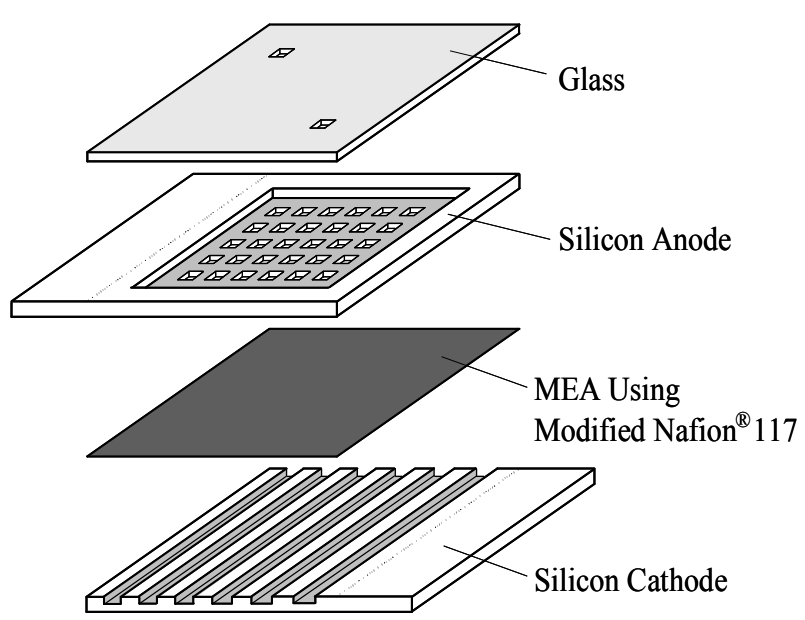

Fig. 5. Schematic view of the $\mu \mathrm{DMFC}$ assembly

After micro fabrication using MEMS technology the final micro direct methanol fuel cell compared with a piece of coin is shown in the digital photograph of figure 6 . The total size of the fuel size is about $10 \mathrm{~mm} \times 8 \mathrm{~mm} \times 3 \mathrm{~mm}$.

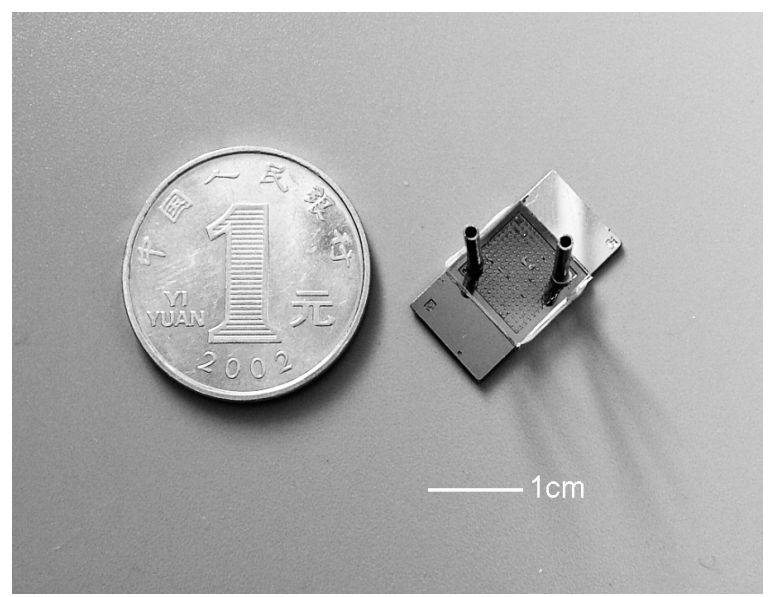

Fig. 6. Photograph of final $\mu \mathrm{DMFC}$

\subsection{Fuel cell performance test set-up}

A custom-built testing system was used to test the micro fuel cell. A peristalsis pump is employed to control the elimination of methanol fuel. At cathode side the oxygen 
was fed using pure oxygen from the cylinder at a measured flow rate using an electronic mass flow controller or was fed directly from the air. The fuel cell working system was kept in a constant temperature container controlled by a thermocouple to keep the operating temperature.

Current-voltage characteristics were measured using two digital multimeters with variable load resistor. The generated current was passed through different loads and the cell voltage was recorded as a function of current once the steady state was achieved. Then the power density curve as a function of current was made.

\section{RESULTS AND DISCUSSION}

Figure 7 shows the current-voltage-power output of micro-fabricated $\mu \mathrm{DMFC}$ with MEA and electro-catalytic electrodes, respectively. The results were gained at room temperature with $2 \mathrm{M}$ methanol, and using air as oxygen fed. Both the MEA and electro-catalytic electrodes provide an $8 \mathrm{~mm} \times 8 \mathrm{~mm}$ contact area to the catalyst with the polymer electrolyte membrane.

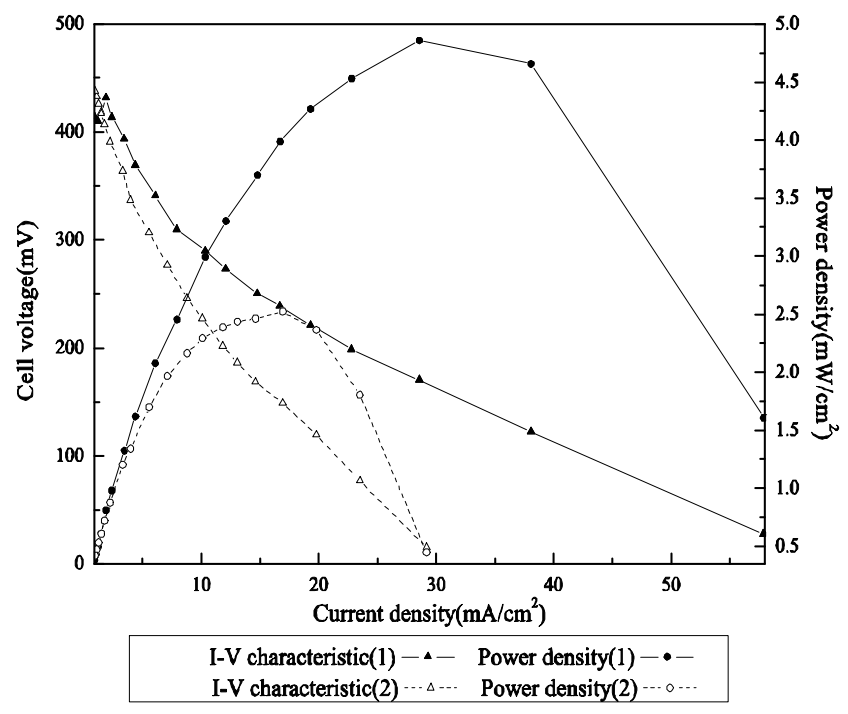

Fig. 7. I-V characteristic and corresponding power density of a $\mu$ DMFC using MEA (1) compared to the performances of a $\mu \mathrm{DMFC}$ using electro-catalytic electrodes (2)

From the polarization curves and current- voltage characteristics we found that the performance of the micro single direct methanol fuel cell with electro-catalytic electrodes did not act as well as expect. The power density of the single cell reached only $2.5 \mathrm{~mW} / \mathrm{cm}^{2}$ much lower than that single cell with traditional MEA $\left(4.9 \mathrm{~mW} / \mathrm{cm}^{2}\right)$ at the same operation conditions. From the results it can be inferred that the scale-down problems were associated more with the catalyst layers than other reasons. Low fuel cell performances reflected a small active catalyst area compared to the whole area of the fuel cell. When integrated the four parts (glass, anode, PEM, cathode) into a whole micro fuel cell, the two substrates deposited with different catalyst may make bad contact with the PEM, thus cause the insufficient activity of the catalysts.

In order to gain information about the active catalyst surface area and the utilization of the catalyst (both anode and cathode), it is necessary to characterize the thin layer of electroless plating catalyst via physisorption (for accessible surface area) and chemisorption (for active site density). These measurements remain as our future research work.

\section{CONCLUSION}

The microfabrication processes which were developed with the progress of MEMS technology provide us a new prospect in the design of small fuel cells. The method of fabrication of electro-catalytic electrodes reported here differs from previous work. Approaches like porous silicon substrates and catalyst deposition using electrochemical anodic etching and electroless plating methods were investigated for improving the effective area of catalyst layer over the PS. The method showed promise and allowed novel catalyst configuration on the porous silicon substrate of the silicon-based $\mu$ DMFC. Such electro-catalytic electrodes helped minimize the fuel cell size, save the usage of rare metals and reduce the contact resistances and at the same time increase the reactive area of the catalyst over the silicon electrode surface.

\section{ACKNOWLEDGEMENTS}

The authors gratefully acknowledge Ms. Cao Shanshan for helping with some experiments. The authors would also like to thank the following colleagues in the Materials Science and Technology College at HIT: Dr. Wu Peilian for EDX and SEM topography, Dr. Du Chunqiu for sputtering work.

\section{REFERENCES}

[1] K. Wozniak, D. Johansson, M. Bring et al "A micro direct methanol fuel cell demonstrator," J. Micromech. Microeng., 14(2004), pp. S59-S63

[2] K. Shah, W.C. Shin, and R.S. Besser, "Novel microfabrication approaches for directly patterning PEM fuel cell membranes," $J$. Power Sources, 123(2003), pp. 172-181

[3] T. Pichonat and B.G. Manuel, "Development of porous silicon-based miniature fuel cells," J. Micromech. Microeng., 15(2005), pp. S179-S184

[4] L.J. Hobson, H. Ozu, M. Yamaguchi et al "Modified Nafion 117 as an improved polymer electrolyte membrane for direct methanol fuel cells," J. Electrochem. Soc., 148(2001), pp. 


\section{A1185-A1190}

[5] T.J. Yen, N. Fang, X. Zhang et al "A micro methanol fuel cell operating at near room temperature," Applied Physics Letters, 83(2003), pp. $4056-4058$

[6] Y. Yamazaki, "Application of MEMS technology to micro fuel cells," Electrochimica Acta, 50(2004), pp. 663-666

[7] K. Shah, W.C. Shin, and R.S. Besser, "A PDMS micro proton exchange membrane fuel cell by conventional and non-conventional microfabrication techniques," Sensors and Actuators B, 97(2004), pp. 157-167

[8] H. Chang, J.R. Kim, J.H. Cho et al "Materials and processes for small fuel cells," Solid State Ionics, 148(2002), pp. 601-606

[9] J. Han and E.S. Park, "Direct methanol fuel-cell combined with a small back-up battery," J. Power Sources, 112(2002), pp 447-483
[10] A. Blum, T. Duvdevani, M. Philosoph et al "Water-neutral micro direct-methanol fuel cell (DMFC) for portable applications," J. Power Sources, 117(2003), pp. 22-25

[11] G.Q. Lu, C.Y. Wang, T.J. Yen et al "Development and characterization of a silicon-based micro direct methanol fuel cell," Electrochimica Acta, 49(2004), pp. 821-828

[12] J.R. Yu, P. Cheng, Z.Q. Ma et al "Fabrication of a miniature twin-fuel-cell on silicon wafer," Electrochimica Acta, 48(2003), pp. 1537-1541

[13] T. Pichonat, B.G. Manuel and D. Hauden, "A new proton-conducting porous silicon membrane for small fuel cells," J. Chemical Engineering, 101(2004), pp. 107-111

[14] S. Gold, K.L. Chun, C. Lu et al "Acid loaded porous silicon as a proton exchange membrane for micro-fuel cells," J. Power Sources, 135(2004), pp. 198-203 